\title{
Persistence of Fusarium oxysporum f. sp. fragariae in Soil Through Asymptomatic Colonization of Rotation Crops
}

\author{
Peter M. Henry, Ana M. Pastrana, Johan H. J. Leveau, and Thomas R. Gordon ${ }^{\dagger}$ \\ Department of Plant Pathology, University of California, Davis 95616, U.S.A. \\ Accepted for publication 7 January 2019.
}

\begin{abstract}
Asymptomatic plant colonization is hypothesized to enhance persistence of pathogenic forms of Fusarium oxysporum. However, a correlation between pathogen populations on living, asymptomatic plant tissues and soilborne populations after tillage has not been demonstrated. Living and dead tissues of broccoli, lettuce, spinach, wheat, cilantro, raspberry, and strawberry plants grown in soil infested with $F$. oxysporum $\mathrm{f}$. sp. fragariae (the cause of Fusarium wilt of strawberry) were assayed to quantify the incidence of infection and extent of colonization by this pathogen. All crops could be infected by $F$. oxysporum $\mathrm{f}$. sp. fragariae but the extent of colonization varied between plant species. Pathogen population densities on nonliving crown tissues incorporated into the soil matrix were typically

greater than those observed on living tissues. Crop-dependent differences in the inoculum density of $F$. oxysporum f. sp. fragariae in soil were only observed after decomposition of crop residue. Forty-four weeks after plants were incorporated into the soil, $F$. oxysporum $\mathrm{f}$. sp. fragariae soil population densities were positively correlated with population densities on plant tissue fragments recovered at the same time point. Results indicate that asymptomatic colonization can have a significant, long-term impact on soilborne populations of Fusarium wilt pathogens. Cultural practices such as crop rotation should be leveraged to favor pathogen population decline by planting hosts that do not support extensive population growth on living or decomposing tissues.
\end{abstract}

Crop rotation can reduce severity and incidence of wilt diseases caused by Fusarium oxysporum (Fang et al. 2011; Gatch and du Toit 2017; Hopkins and Elmstrom 1984; Nageswara Rao et al. 2014; Toledo-Souza et al. 2012; Wang et al. 2015). However, not all crop rotations lead to reduced disease pressure (Fang et al. 2011; Hopkins and Elmstrom 1984; Nageswara Rao et al. 2014; ToledoSouza et al. 2012; Wang et al. 2015). Soil populations of Fusarium wilt pathogens are likely to decrease substantially within 1 to 3 years under fallow conditions (Banihashemi and Dezeeuw 1973; Elmer and Lacy 1987; Gordon and Koike 2015; Rishbeth 1955; Scott et al. 2012; Stover 1956; Vakalounakis and Chialkas 2004) but a very broad range of plant hosts can be colonized asymptomatically by pathogenic forms of F. oxysporum (Gordon et al. 1989; Haware and Nene 1982; Scott et al. 2014). Some plants support relatively high populations of Fusarium wilt pathogens and have a greater potential to increase inoculum (Dhingra and Coelho Netto 2001). It is hypothesized that differences in the efficacy of crop rotations are explained by corresponding differences in plant tissue colonization (Gordon 2017).

The relative risk of rotation with a particular crop is frequently estimated by quantifying pathogen biomass in living plant tissues (Dhingra and Coelho Netto 2001; Haware and Nene 1982; Leoni et al. 2013; Pastrana et al. 2017a; Scott et al. 2014). The extent of colonization of senescent or nonliving tissue is less commonly examined. F. oxysporum f. sp. melonis populations on the roots of seven crops were found to significantly increase within 5 days after

†Corresponding author: T. R. Gordon; E-mail: trgordon@ucdavis.edu

Funding: Support for this research was provided by the Storkan-Hanes-McCaslin Foundation, the Western Sustainable Agricultural Research and Education Program (WSARE) (Graduate Student Grant GW17-032), the California Strawberry Commission, the United States Department of Agriculture- Contract-Sponsor through Hatch project CA-D-PPA-6699-H, and the National Science Foundation Graduate Research Fellowship Program.

*The $\boldsymbol{e}$-Xtra logo stands for "electronic extra" and indicates that one supplementary table and three supplementary figures are published online.

The author(s) declare no conflict of interest.

(c) 2019 The American Phytopathological Society plants were severed at the soil line (Gordon and Okamoto 1990). To the extent that pathogen growth occurs in senescing or decomposing tissue, colonization of living tissues may not indicate the true potential for a crop to increase soilborne inoculum. A combination of experiments that quantify inoculum densities on living and decomposed plant tissues, and a comparison of these values with soil populations after plant tissue incorporation, would help to establish protocols for identifying crops that support increases in populations of Fusarium wilt pathogens. Such experiments could test the implicit hypothesis that inoculum densities on living plant tissues are predictive of soilborne inoculum after tillage.

Fusarium wilt of strawberry, caused by $F$. oxysporum f. sp. fragariae, is a disease of serious concern for strawberry production regions worldwide, including those in California. A major gene for resistance to Fusarium wilt was recently identified in the University of California breeding population (Pincot et al. 2018); however, most commonly grown cultivars are susceptible. Furthermore, the best available fumigation practices do not provide complete control of this pathogen when susceptible cultivars are grown (M. Bolda, personal communication; Koike and Gordon 2015). Both conventional and organic strawberry growers in California have shown interest in using crop rotation for disease control (Lloyd 2015), but the potential for crops commonly grown in California strawberry production regions to become colonized by $F$. oxysporum f. sp. fragariae remains unexplored. Therefore, experimental validation is required to ensure that crop rotations do not facilitate persistence of this pathogen in soil.

The objectives of this study were to (i) assess the population density of $F$. oxysporum f. sp. fragariae on four types of living tissues of diverse hosts (including fine roots, transport roots, taproot or crown cortex, and taproot or crown stele), (ii) determine whether pathogen population density in host tissues increases after incorporating these tissues into the soil, and (iii) evaluate the correlation between population density on decomposing host tissues and persistence in soil over time.

\section{MATERIALS AND METHODS}

Fungal transformation. To facilitate detection in plant tissues and soil, a known pathogenic isolate of $F$. oxysporum $\mathrm{f}$. sp. fragariae 
(GL1080) (Henry et al. 2017) was transformed to obtain an antibiotic-selectable strain using a protocol described by Pareek et al. (2015). Isolate GL1080 is in the somatic compatibility group CA-SCG1, which accounted for $91.5 \%$ of $F$. oxysporum f. sp. fragariae isolates tested in California between 2008 and $2014(n=$ 59) (Henry et al. 2017). Agrobacterium tumefaciens strain AGL-1 containing the pBHt2 vector (Mullins et al. 2001) (kindly provided by Dr. Richard Bostock, Department of Plant Pathology, University of California-Davis) was grown on a Lysogeny broth (LB) agar plate supplemented with kanamycin $(50 \mu \mathrm{g} / \mathrm{ml})$ at $28^{\circ} \mathrm{C}$ for 2 days in darkness. LB supplemented with kanamycin $(50 \mu \mathrm{g} / \mathrm{ml})$ and rifampicin $(50 \mu \mathrm{g} / \mathrm{ml})$ was inoculated with a single colony and incubated for $20 \mathrm{~h}$ at $28^{\circ} \mathrm{C}$ on a rotary shaker at $250 \mathrm{rpm}$. Cells were centrifuged, washed twice with sterile deionized water, resuspended to an optical density at $600 \mathrm{~nm}$ of 0.15 in induction medium containing $200 \mu \mathrm{M}$ acetosyringone (Bundock et al. 1995), and incubated for $4 \mathrm{~h}$ at $28^{\circ} \mathrm{C}, 250 \mathrm{rpm}$.

The optimum concentration of hygromycin B and cefotaxime for transformation was determined as described by Yuan et al. (2014). GL1080 was cultured on potato dextrose agar (PDA) for 10 days at room temperature. Spores were scraped from the surface of culture plates by adding sterile deionized water and scraping gently with a sterile glass rod. The resulting suspension was filtered through two layers of sterile cheesecloth and the filtrate was centrifuged at $2,000 \times g$ and $4^{\circ} \mathrm{C}$ for $10 \mathrm{~min}$. The pellet was washed twice with sterile deionized water and diluted to a density of $10^{6}$ spores $/ \mathrm{ml}$.

The suspension of $F$. oxysporum $\mathrm{f}$. sp. fragariae spores was mixed in a 1:1 ratio with acetosyringone-induced Agrobacterium culture. The combined suspensions $(200 \mu \mathrm{l})$ were spread on nitrocellulose membranes (Whatman, catalog number 7141-104) and placed on the agar surface of induction medium containing $200 \mu \mathrm{M}$ acetosyringone. Other nitrocellulose membranes were inoculated with only the fungal spore suspension (no Agrobacterium) as a negative control. Plates were incubated at $28^{\circ} \mathrm{C}$ for 2 days, after which the membrane was transferred to $F$. oxysporum minimal medium agar plates (Correll et al. 1987) containing hygromycin B (100 mg/liter) and cefotaxime (300 mg/liter). Hygromycin B-resistant fungal colonies appeared after 7 days of incubation at $25^{\circ} \mathrm{C}$. No colonies were observed growing from the negative control membranes.

To check for phenotypic stability, transformed colonies were serially transferred five times on PDA plates containing hygromycin B (100 mg/liter) and cefotaxime (300 mg/liter). DNA was isolated from transformants as described by Pastrana et al. (2017b). To confirm the integration of the hygromycin B phosphotransferase gene $(h p h)$, an approximately 1-kbp fragment was amplified in a polymerase chain reaction (PCR) using primers HPH-F and HPH-R (Kemppainen et al. 2005). Transformants were single hyphal tipped and stored on dried filter paper (Gordon and Okamoto 1991). One of these transformants (GL1080-K) was used in subsequent experiments.

Root tip colonization in naturally infested field soil. The substrate used in these experiments was a 3:2 mixture of field soil naturally infested with $F$. oxysporum $\mathrm{f}$. sp. fragariae and autoclaved fine white sand (Capitol Sand and Gravel). Field soil was obtained in August 2015 from a commercial field in Ventura County with a history of Fusarium wilt of strawberry, and all isolates from these soils were in the same somatic compatibility group as GL1080-K (Henry et al. 2017). The soil-sand mixture was prepared just prior to the start of each experiment (repeated three times).

Inoculum density of $F$. oxysporum $\mathrm{f}$. sp. fragariae in the soil-sand mixture was estimated using soil dilution plating (Henry et al. 2017), followed by a PCR test of putative pathogen colonies using primers described by Suga et al. (2013). Previous experiments showed that $96.8 \%$ of $F$. oxysporum f. sp. fragariae isolates from this soil could be identified by the FofraF/FofraR primer pair (Henry et al. 2017). DNA was extracted by methods described by Henry et al. (2017). PCR verification was conducted as per Suga et al.
(2013), with the following modifications. The PCR mixture $(25 \mu \mathrm{l})$ contained $1 \times$ GoTaq Green Master Mix, $0.4 \mu \mathrm{M}$ FofraF and FofraR primers, and genomic DNA at 40 to $100 \mathrm{ng} / \mu \mathrm{l}$. Two technical replicates of the soil assay were conducted at the beginning of each experiment. Results from these assays were averaged to determine the mean abundance of $F$. oxysporum $\mathrm{f}$. sp. fragariae in the soil of each experiment.

Seed (wheat, spinach, lettuce, broccoli, and cilantro) and dormant crowns (strawberry and raspberry) of the general rotation crop panel (Table 1) were planted in number 1 Sunshine Mix (Sun Gro Horticulture) and maintained in a growth chamber with day and night temperatures of 28 and $20^{\circ} \mathrm{C}$, respectively; a 12-h photoperiod; and medium-intensity high-pressure sodium and metal halide lamps. A nutrient solution containing $\mathrm{NH}_{4}-\mathrm{N}$ at $5.99 \mathrm{mg} / \mathrm{liter}, \mathrm{NO}_{3}-\mathrm{N}$ at $70.39 \mathrm{mg} /$ liter, $\mathrm{P}$ at $53.92 \mathrm{mg} / \mathrm{liter}, \mathrm{K}$ at $113.83 \mathrm{mg} / \mathrm{liter}, \mathrm{Ca}$ at $170.75 \mathrm{mg} / \mathrm{liter}, \mathrm{Mg}$ at $29.35 \mathrm{mg} / \mathrm{liter}$, and $\mathrm{S}$ at $38.64 \mathrm{mg} /$ liter was used for irrigation. Fourteen days later, the seedlings or crowns were removed from the soil, washed of adhering soil particles, and transplanted into 2-liter pots containing the soil-sand mixture. The 2-liter pots were then returned to the growth chamber and irrigated as necessary. Twenty days later, the soil was gently removed from the pot and all soil and roots within $1 \mathrm{~cm}$ of the side and bottom of the pot were discarded. The remaining soil was washed away from fine roots over a 4-mm mesh sieve. Roots were collected, washed three times in fresh $1 \%$ sodium hexametaphosphate solution (to improve soil aggregate dispersal) by shaking at $100 \mathrm{rpm}$ for $15 \mathrm{~min}$, and sonicated in a Branson 5510 water bath for 7 min (Kettler et al. 2001).

Root tips (containing apical meristem) that were 15 to $20 \mathrm{~mm}$ in length were placed on Komada's Medium (KM) (Komada 1975) and incubated under continuous fluorescent lighting at room temperature for 7 days. Colonies similar in morphology to F. oxysporum f. sp. fragariae were subcultured and checked for identity using the PCR test described above. For each plant, 30 to 50 root tips were assayed and the proportion of root tips infected over the total number of root tips was determined. The proportion of infected root tips was arcsin(square root) transformed prior to statistical analysis to achieve a normal distribution.

F. oxysporum f. sp. fragariae population density on living plant tissues. Hygromycin-resistant $F$. oxysporum f. sp. fragariae

TABLE 1. Crops and cultivars used in this study

\begin{tabular}{|c|c|c|c|}
\hline \multirow[b]{2}{*}{ Crop (species), cultivar } & \multicolumn{3}{|c|}{ Panel $^{\mathrm{z}}$} \\
\hline & General & Strawberry & Lettuce \\
\hline \multicolumn{4}{|l|}{ Lettuce (Lactuca sativa) } \\
\hline Green Towers & $\mathrm{X}$ & $\ldots$ & $\mathrm{X}$ \\
\hline Salute & $\ldots$ & $\ldots$ & $\mathrm{X}$ \\
\hline Salinas 88 & $\ldots$ & $\ldots$ & $\mathrm{X}$ \\
\hline Bondi & $\ldots$ & $\ldots$ & $\mathrm{X}$ \\
\hline \multicolumn{4}{|c|}{ Broccoli (Brassica oleracea) } \\
\hline Marathon F1 & $\mathrm{X}$ & $\cdots$ & $\cdots$ \\
\hline \multicolumn{4}{|l|}{ Wheat (Triticum aestivum) } \\
\hline Summit & $\mathrm{X}$ & $\cdots$ & $\cdots$ \\
\hline \multicolumn{4}{|c|}{ Cilantro (Coriandrum sativum) } \\
\hline Leisure & $\mathrm{X}$ & $\ldots$ & $\ldots$ \\
\hline \multicolumn{4}{|c|}{ Spinach (Spinacia oleracea) } \\
\hline Whale F1 & $\mathrm{X}$ & $\ldots$ & $\ldots$ \\
\hline \multicolumn{4}{|l|}{ Raspberry (Rubus idaeus) } \\
\hline Heritage & $\mathrm{X}$ & $\ldots$ & ... \\
\hline \multicolumn{4}{|c|}{ Strawberry (Fragaria $\times$ ananassa) } \\
\hline Albion & $\mathrm{X}$ & $\mathrm{X}$ & $\mathrm{X}$ \\
\hline Monterey & $\cdots$ & $\mathrm{X}$ & $\ldots$ \\
\hline San Andreas & $\mathrm{X}$ & $\mathrm{X}$ & $\ldots$ \\
\hline Fronteras & $\ldots$ & $\mathrm{X}$ & $\ldots$ \\
\hline Portola & $\ldots$ & $X$ & $\ldots$ \\
\hline Ventana & $\ldots$ & $X$ & $\ldots$ \\
\hline
\end{tabular}

z Each "panel" (i.e., general, strawberry, and lettuce) is a set of crops/cultivars used in a series of experiments. All cultivars which were included in a panel are marked with an $\mathrm{X}$ in the corresponding panel column. 
strain GL1080-K was grown on 18 PDA plates $(100 \mathrm{~mm}$ in diameter) for 14 days at room temperature under continuous fluorescent lighting. GL1080-K-colonized agar was removed from the petri dishes and blended with $500 \mathrm{ml}$ of sterile deionized water for $1 \mathrm{~min}$ in a Waring Commercial blender (Waring Commercial Products), at which point the suspension was a homogenous, viscous slurry with no agar chunks. The slurry was hand mixed with 10 liters of autoclaved fine white sand (Capitol Sand and Gravel) until homogenous and air dried for 10 days at $25^{\circ} \mathrm{C}$. Inoculated sand was remixed daily during the drying period. Dry, infested sand was stored at $4^{\circ} \mathrm{C}$ for up to 3 weeks prior to use. Prior to each experiment, 10 liters of infested sand was blended with 70 liters of number 1 Sunshine Potting Mix (Sun Gro Horticulture) to obtain an inoculum density of approximately $2 \times 10^{5} \mathrm{CFU} / \mathrm{g}$ of sand-potting soil mix. The inoculum density of the infested sand-potting soil mixture was verified by dilution plating on $\mathrm{KM}$ amended with hygromycin $\mathrm{B}$ (100 mg/liter).

Experiments using the general panel of rotation crops (Table 1) were conducted three times to estimate $F$. oxysporum $\mathrm{f}$. sp. fragariae population density in plant tissues. Three plants (= biological replicates) were assayed for each crop type. Seed and transplants were sown in number 1 Sunshine Potting Mix and grown for 14 days in a growth chamber with the previously described settings (Root tip colonization section). Seedlings were then removed from their pots $(n=3)$, washed to remove adhering soil, and transplanted into the infested sand-potting soil mix described above. Plants were returned to the growth chamber and maintained for a period of 6 weeks.

At the end of this growth period, plants were washed and separated into the following tissue types (McCormack et al. 2015): fine roots ( $<2 \mathrm{~mm}$ in diameter, proximal to apical meristem tissues), transport roots ( $\geq 2 \mathrm{~mm}$ in diameter, proximal to taproot or crown), taproot or crown cortical tissue, and taproot or crown stele tissue. Roots $>2 \mathrm{~mm}$ in diameter (transport roots) were only found on strawberry and raspberry plants. Taproots (broccoli, lettuce, spinach, and cilantro) and root crowns (wheat, raspberry, and strawberry) were defined, in all cases, as the belowground enlarged root tissues that are immediately basal to the stem. Stele tissues from spinach and wheat plants were too small to separate from cortical tissues. Fine roots and transport roots were collected from the center of the pot, washed three times in $1 \%$ sodium hexametaphosphate solution, and sonicated for $7 \mathrm{~min}$ in a Branson 5510 sonicator. Taproots or crowns were surface-sterilized by rinsing in $0.1 \%$ Tween 20 solution, submerging for $10 \mathrm{~s}$ in $70 \%$ ethanol, immersing in $1 \%$ sodium hypochlorite (with continuous agitation from a magnetic stir bar) for $2 \mathrm{~min}$, and drying thoroughly (solution percentages are volume/volume). After surface disinfestation, fresh weight was recorded for each tissue type of each plant, and tissues were blended with deionized water for $5 \mathrm{~min}$ in a Waring commercial blender. The resulting slurry was spread over the surface of KM amended with hygromycin B (100 mg/liter) to achieve a final detection limit of approximately $500 \mathrm{CFU} / \mathrm{g}$ of plant tissue. Plates were incubated at room temperature under continuous fluorescent lighting for 6 to 7 days prior to counting the number of colonies with GL1080-K morphology.

We used the same experimental procedure (with three independent repetitions) on two additional crop panels: a selection of F. oxysporum f. sp. fragariae-resistant and -susceptible strawberry cultivars, and a panel of lettuce cultivars (Table 1). For the experiments with resistant and susceptible strawberry cultivars, four plants (= biological replicates) were used and the growth chamber had day and night temperatures of 25 and $18^{\circ} \mathrm{C}$, respectively. The lettuce cultivar experiments were conducted exactly as described for the general panel of rotation crops but with four biological replicates, and only the taproot or crown cortex and stele tissues were assayed.

F. oxysporum f. sp. fragariae population density on plant tissues buried in soil for 2 weeks. Two experiments were conducted to quantify $F$. oxysporum f. sp. fragariae population density on taproot or crown tissues after 2 weeks of burial in soil. Initial inoculation, cultivar selection, and growth conditions were exactly as described for experiments assaying population density of GL1080-K on living tissues of the general rotation crop panel (Table 1). However, tissues were not assayed immediately after the 6-week growth period. Instead, taproots or crowns were removed from the soil, trimmed of roots longer than $2 \mathrm{~cm}$, severed from aboveground biomass $2 \mathrm{~cm}$ above the soil line, and reburied in the pot from which they came. Pots were irrigated with a nutrient solution (described above) as needed to maintain soil near field capacity for 14 days, and taproots or crowns were then recovered. Cortex and stele compartments could not be distinguished after the incubation period; therefore, whole taproot or crown pieces were cleaned of adhering soil particles, surface sterilized with $1 \%$ sodium hypochlorite, and assayed for GL1080-K population density, as described above.

Survival of $F$. oxysporum f. sp. fragariae in soil for 44 weeks after crop growth and plant tissue incorporation. Seed of five rotation crops and dormant strawberry crowns were sown in potting soil (number 1 Sunshine Mix; Sun Gro Horticulture) and cultivated in a growth chamber with a 12 -h photoperiod and day and night temperatures of 28 and $20^{\circ} \mathrm{C}$, respectively for 14 days prior to the start of the experiment. Living raspberry primocanes (first-year cane growth) were maintained in the same growth chamber. After 14 days, potting soil was gently washed from roots of all plants, and four plants per crop were transplanted into 2-liter pots (= four biological replicates, one plant per pot). These 2-liter pots contained a soil mixture that was prepared by mixing 10 liters of sand infested with GL1080-K (prepared as described above), 15 liters of autoclaved fine white sand (Capitol Sand and Gravel), and 63 liters of soil from a strawberry field near Watsonville, CA which had been passed through a 4-mm mesh sieve. The soil-sand mixture was prepared immediately before the start of each experiment, and consisted of 78 to $80 \%$ sand, 6 to $8 \%$ silt, and $14 \%$ clay (texture analysis was conducted by A \& L Western Agricultural Laboratories). An additional four pots were left unplanted as a "fallow" treatment. Planted and fallow pots were returned to the same growth chamber used to generate the transplants for these experiments.

Six weeks later, plants were severed at the soil line, and fresh weight of aboveground plant biomass was recorded. All plant tissues (including roots) were cut into approximately $1-\mathrm{cm}$ fragments and mixed evenly with the soil, which was returned to the pot from which it was removed. For the fallow treatment (no plants), soil was removed, mixed, and returned to the pot. All pots were returned to the growth chamber, left to dry for 1 week, and irrigated weekly thereafter with $200 \mathrm{ml}$ of charcoal-filtered water per pot.

At the time of plant tissue incorporation and 12, 24, and 44 weeks postincorporation (wpi), the soil was removed from each pot and thoroughly mixed by hand, and approximately $150 \mathrm{~g}$ of soil (excluding large tissue fragments) was retrieved for quantification of GL1080-K population density. The abundance of GL1080-K in the soil was quantified using soil dilution plating on KM amended with hygromycin B (100 mg/liter). Two technical replicates were conducted per biological replicate at each time point and the average of these two technical replicates was used in statistical analyses.

At the final time point (44 wpi), soil was passed through a $4-\mathrm{mm}$ mesh sieve and plant tissue fragments larger than $4 \mathrm{~mm}$ were collected and dried at $30^{\circ} \mathrm{C}$ for $24 \mathrm{~h}$. Tweezers were used to scrape large adhering soil particles from the surface of tissues, which were not otherwise cleaned. Strawberry tissues were separated into transport roots and crown tissues based on clear morphological differences (Supplementary Fig. S1). Tissues were weighed and ground into a fine powder with a mortar and pestle. This powder was suspended in $1 \%$ sodium hexametaphosphate and dispensed onto $\mathrm{KM}$ amended with hygromycin B at $100 \mathrm{mg} /$ liter (detection limit was between 8 and 1,000 CFU/g). 
Statistical analysis. All statistical analyses were conducted in R (version 3.4.3) (R Core Team 2013). Levene's test ("leveneTest", package = "car") was used to assess homogeneity of variance (Fox and Weisberg 2011), and normality was checked by generating quantile-quantile plots ("qqnorm", package = "stats"). For data with a continuous response variable, linear mixed-effects models were fit by "lmer" from the "lmerTest" package (Kuznetsova et al. 2017). For the full mixed model, crop type was coded as a fixed effect, while experiment and experiment-crop interactions were coded as random effects. The $\chi^{2}$ tests were conducted between the full model and models where one random effect was removed to test the significance of the removed variables ("anova" with "type = Chisq", package $=$ "ImerTest"). Two-way analyses of variance (ANOVAs) were conducted with "anova" from the "lmerTest" package. Multiple tissue types from a single plant or separate time points in the soil survival experiments were not considered independent variables; therefore, separate two-way ANOVAs were conducted for each tissue type or time point. Paired and Welches $t$ tests were conducted with "t.test" (package = "stats"), and "p.adjust" with "method = bonferroni" used to correct for multiple comparisons. Tukey's honestly significant difference (HSD) tests for multiple comparisons were conducted with "HSD.test" from the "agricolae" package $(\alpha=0.05)$ (de Mendiburu 2017). The "cor.test" (package $=$ "stats") was used to test the significance of correlation (method = "pearson"). $R^{2}$ values were calculated by "lm" (package = "stats").

\section{RESULTS}

A. tumefaciens-mediated transformation of $\boldsymbol{F}$. oxysporum f. sp. fragariae. Coincubation of fungal spores and A. tumefaciens cells led to the emergence of two to five hygromycin B-resistant colonies of $F$. oxysporum $\mathrm{f}$. sp. fragariae per plate. PCR products of the expected size (approximately $1.0 \mathrm{~kb}$ ) were obtained from 12 transformants using HPH primers (specific for the hygromycin gene, $h p h$ ). Of those 12 transformants, 6 were confirmed to have retained pathogenicity on the strawberry cultivar Albion and to have growth rates on PDA and KM which were indistinguishable from that of the wild-type isolate (data not shown). A single transformant resulting from this protocol, called GL1080-K, was used in subsequent experiments.

Root tip colonization in naturally infested field soil. All crops tested in these experiments sustained root tip infections by F. oxysporum f. sp. fragariae. The highest rates of root infection were observed on Fusarium wilt-susceptible strawberry cultivar Albion, resistant strawberry cultivar San Andreas, and raspberry (Fig. 1). The lowest root infection rates were observed on broccoli and spinach plants (Fig. 1). A two-way ANOVA revealed a significant effect of crop on the frequency of root tip infection $(P<$ $0.001)$, whereas experiment and crop-experiment interaction were not significant $(P=0.183$ and $P>0.999$, respectively). Mean inoculum densities of $F$. oxysporum $\mathrm{f}$. sp. fragariae ( \pm standard error) were $380( \pm 127), 260( \pm 70)$, and $540( \pm 42)$ at the start of experiments one, two, and three, respectively. Soil inoculum density was positively correlated with the frequency of root infection (total infected roots/total roots assayed) across the three experiments ( $n=3, R^{2}=0.99, P=0.023$, data not shown).

$F$. oxysporum f. sp. fragariae population density on living plant tissues. General rotation crop panel. After 6 weeks of growth in soil infested with $F$. oxysporum f. sp. fragariae (isolate GL1080-K), the pathogen was detected on the taproots, crowns, or fine roots of all tested rotation crops (Table 2). Raspberry transport roots contained the highest mean population of any living tissue from a nonstrawberry crop, and these were not significantly different from transport roots of susceptible strawberry (Table 2). Logarithmic (base 10) transformation was conducted on CFU counts +1 to achieve a log-normal distribution. Two-way ANOVAs from crown cortex, crown stele, and fine roots revealed a highly significant effect of crop $(P \leq 0.006)$ and no significant effects of experiment or crop-experiment interaction $(P \geq 0.711)$.

Fine roots appear to be an important site of inoculum production on lettuce, spinach, broccoli, cilantro, and wheat. For example, population densities of GL1080-K on cilantro fine roots were significantly higher than cilantro taproot cortex (paired $t$ test, Bonferroni corrected $P<0.001$ ). In contrast, fine root population densities were significantly lower than populations in crown cortex tissues of both strawberry cultivars (paired $t$ test with Bonferroni correction; San Andreas, $P=0.039$ and Albion, $P<0.001$ ). This suggests that fine roots are less important for production of soilborne inoculum on strawberry and raspberry plants, because greater population densities are produced on other tissues.

Resistant and susceptible strawberry cultivars. After 14 days of growth in infested soil, population densities of GL1080-K were determined for transport roots, crown cortices, crown steles, and petiole tissues of all six cultivars (Fig. 2A). Two-way ANOVAs revealed cultivar to be a significant source of variation for all tissue types $(P<0.001)$, whereas experiment and crop-experiment interaction were not significant $(P \geq 0.321)$. Tukey's HSD showed population densities of GL1080-K to be significantly lower in resistant cultivars than in susceptible cultivars for all tissue types (Fig. 2B). Both susceptible cultivars (Albion and Monterey) had higher densities of F. oxysporum $\mathrm{f}$. sp. fragariae in stelar tissues than in cortices. The difference was significant for Albion $(P=0.036)$ but not Monterey $(P=0.101)$ (Fig. 2B). In contrast, all resistant cultivars had significantly lower population densities in the stele than in the cortex $(P \leq 0.002)$ (Fig. 2B).

Lettuce cultivar panel. GL1080-K population densities were quantified from the taproot cortex and stele tissues of four lettuce cultivars differing in susceptibility to Fusarium wilt of lettuce and

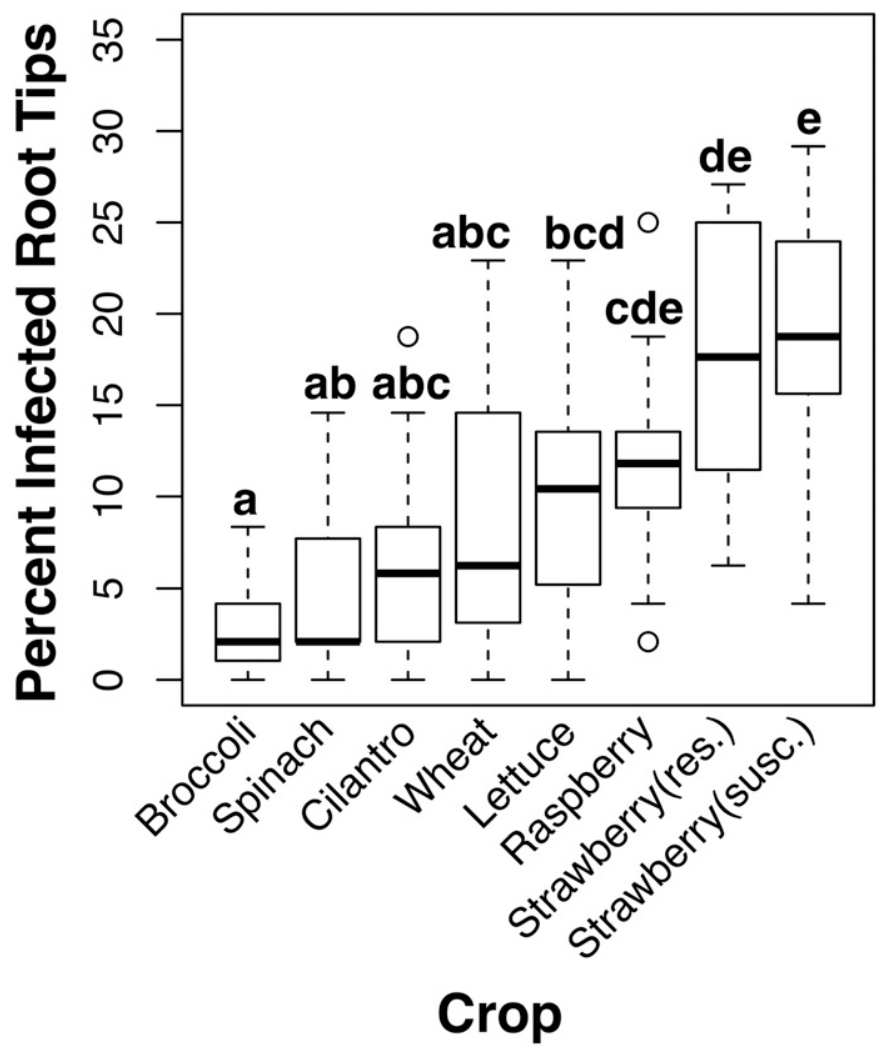

Fig. 1. Box plot depicting the rate of root tip infection by Fusarium oxysporum f. sp. fragariae in naturally infested soil. Strawberry cultivars San Andreas and Albion are resistant and susceptible to Fusarium wilt, respectively. Tukey's honestly significant difference statistical groupings were determined from $\arcsin$ (squared root) transformed data. Boxplots with the same letter are not significantly different $(\alpha=0.05)$. 
the susceptible strawberry cultivar Albion. F. oxysporum f. sp. fragariae was not detected in either the cortex or the stele of the lettuce cultivar Salinas 88 but was recovered from the stele of all other lettuce cultivars (Table 3), including two cultivars with resistance to Fusarium wilt of lettuce (caused by F. oxysporum f. sp. lactucae). For both cortical and stelar tissues, two-way ANOVA revealed cultivar to be a significant source of variation in GL1080-K population densities, reflecting significantly higher levels in strawberry than in any of the lettuce cultivars (Table 3 ).

F. oxysporum $f$. sp. fragariae population density on plant tissues buried in soil for 2 weeks. Taproot or crown tissues recovered 2 weeks post burial were not separated into cortex and stele (as

TABLE 2. Colonization of living rotation crop tissues by Fusarium oxysporum f. sp. fragariae (strain GL1080-K) ${ }^{\mathrm{x}}$

\begin{tabular}{|c|c|c|c|c|c|}
\hline \multirow[b]{2}{*}{ Crop (cultivar) ${ }^{\mathrm{y}}$} & \multirow[b]{2}{*}{ Fine root } & \multirow[b]{2}{*}{ Transport root } & \multicolumn{3}{|c|}{ Taproot or crown } \\
\hline & & & Cortex & Stele & Total $^{\mathrm{z}}$ \\
\hline Lettuce (Green Towers) & $0(0.0) \mathrm{b}$ & NT & $0.27(0.25) \mathrm{a}$ & $0(0.0) \mathrm{a}$ & $0.24(0.24) \mathrm{a}$ \\
\hline Spinach (Whale) & $1.74(0.41) \mathrm{ab}$ & NT & NT & NT & $0.62(0.41) \mathrm{a}$ \\
\hline Broccoli (Marathon F1) & $0.84(0.4) a b$ & NT & $0.27(0.25) \mathrm{a}$ & $0.24(0.22) \mathrm{a}$ & $0.25(0.24) \mathrm{a}$ \\
\hline Cilantro (Leisure) & $1.92(0.34) \mathrm{a}$ & NT & $0.0(0.0) \mathrm{a}$ & $0(0.0) \mathrm{a}$ & $0(0) \mathrm{a}$ \\
\hline Wheat (Summit) & $0.85(0.4) a b$ & NT & NT & NT & $0.3(0.3) \mathrm{a}$ \\
\hline Raspberry (Heritage) & $0.52(0.35) \mathrm{ab}$ & $3.15(0.45) \mathrm{a}$ & $0.55(0.35) \mathrm{a}$ & $0.7(0.34) \mathrm{a}$ & $0.84(0.36) \mathrm{a}$ \\
\hline Strawberry (San Andreas) & $1.42(0.54) \mathrm{ab}$ & $2.57(0.76) \mathrm{a}$ & $3.09(0.43) \mathrm{b}$ & $0.24(0.23) \mathrm{a}$ & $2.78(0.44) \mathrm{b}$ \\
\hline Strawberry (Albion) & $0.27(0.25) \mathrm{ab}$ & $2.93(0.4) \mathrm{a}$ & $4.35(0.33) b$ & $5.04(0.21) \mathrm{b}$ & $4.93(0.23) \mathrm{c}$ \\
\hline
\end{tabular}

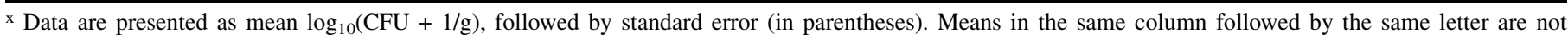
significantly different by Tukey's honestly significant difference test for multiple comparisons $(\alpha=0.05)$. NT $=$ tissue type was not tested.

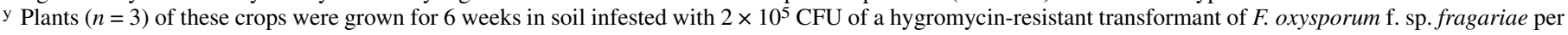
gram of soil. The abundance of the transformant was then quantified from root tissues.

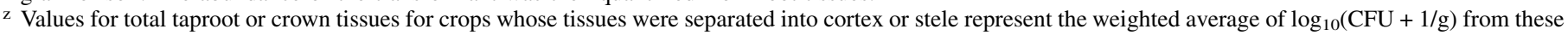
tissues (i.e., $\log _{10}[\mathrm{CFU}+1 / \mathrm{g}]$ normalized to the observed weight).

A

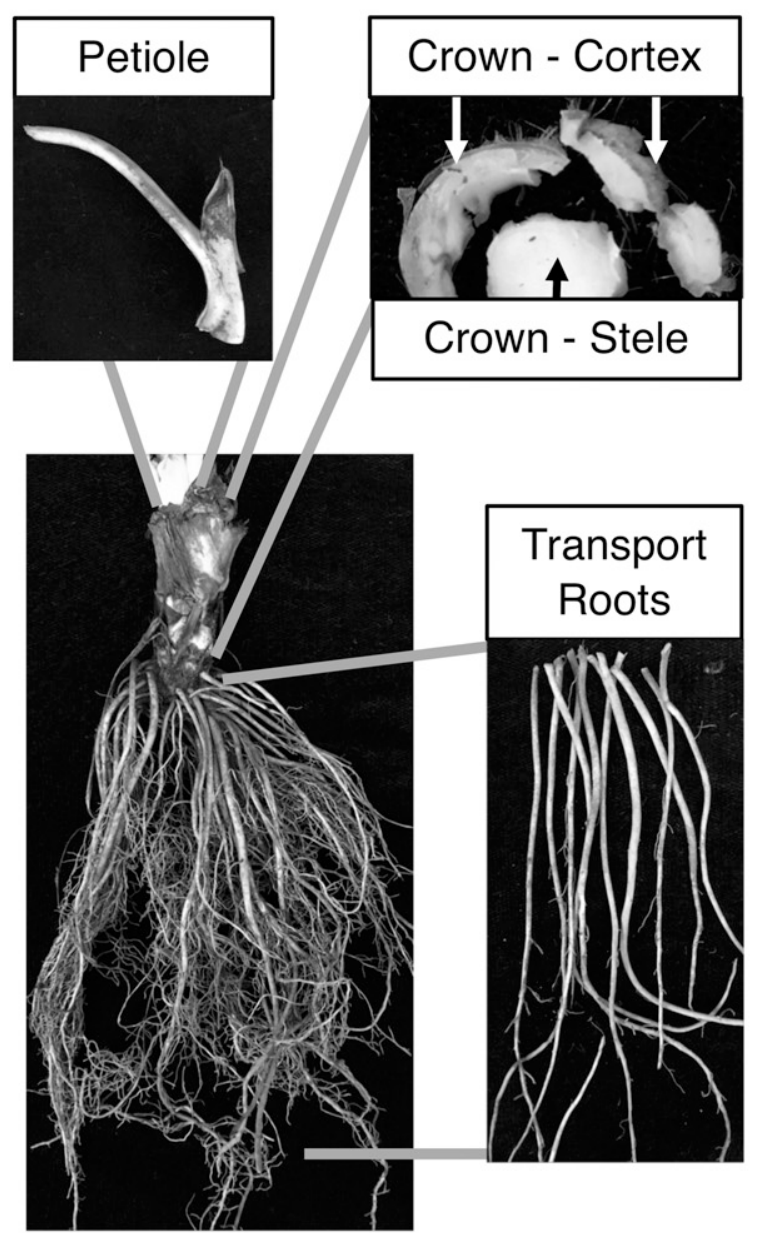

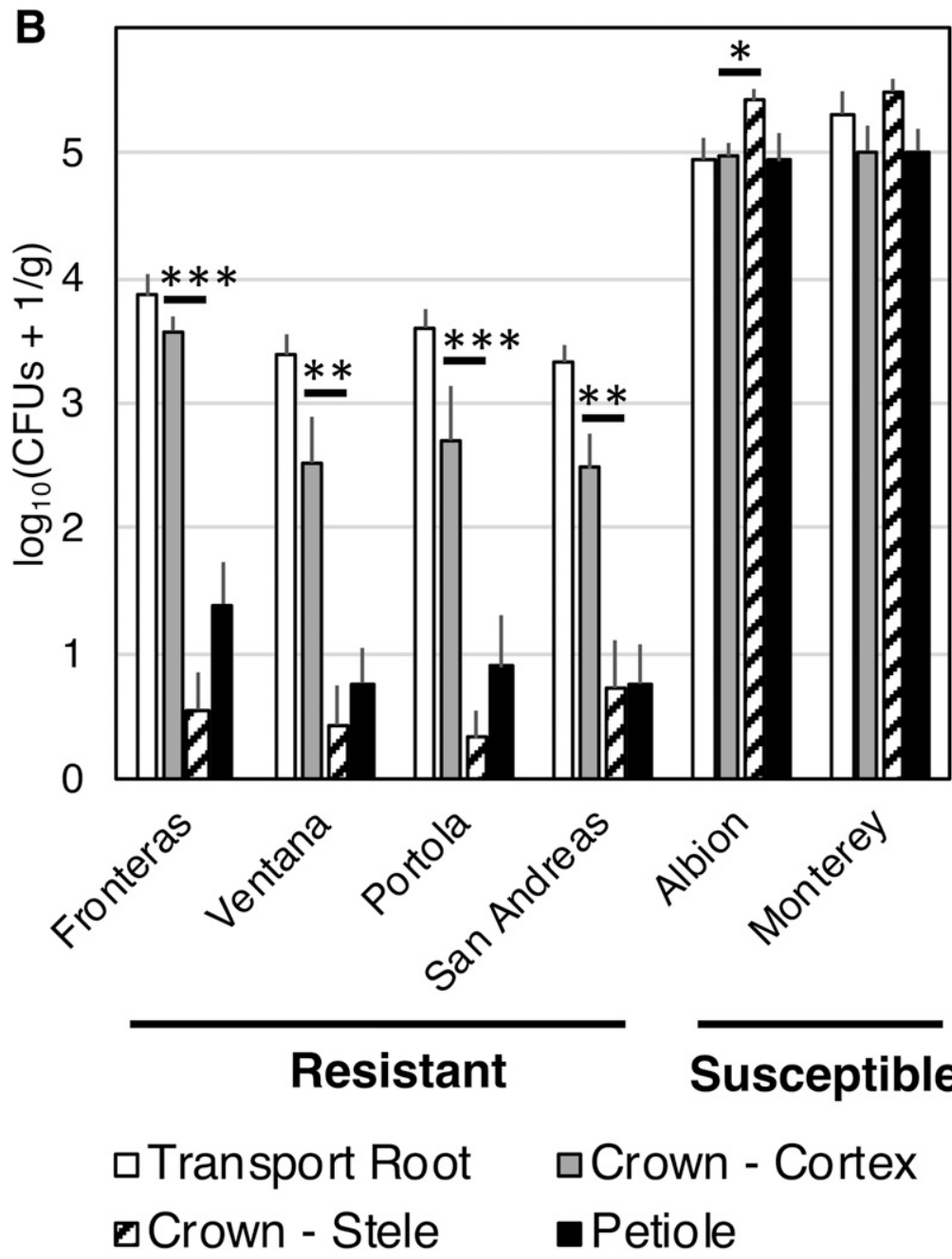

B

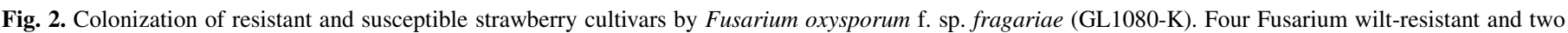

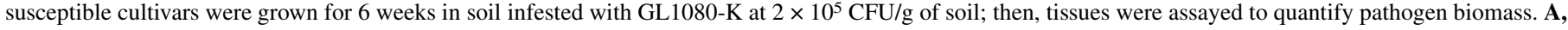

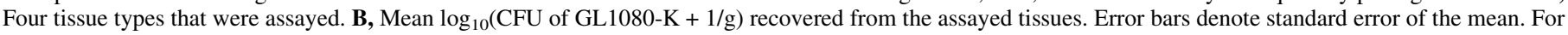

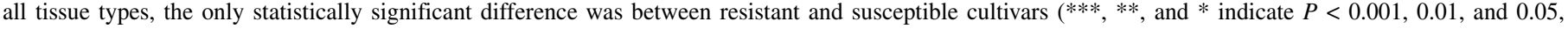
respectively). 
living tissues were); therefore, total GL1080-K CFU/g in living taproot or crown tissues was calculated from the weighted average of cortex and stele population densities (Table 2). Welch's twosample $t$ test was used to evaluate differences in $\log _{10}$ (GL1080-K $\mathrm{CFU}+1 / \mathrm{g}$ ) between living and postburial taproots or crowns for each crop, with Bonferroni correction for multiple comparisons applied to all $P$ values (Fig. 3). GL1080-K population densities were significantly greater after taproot or crown burial for broccoli, spinach, cilantro, and wheat $(P=0.002,0.015,0.033$, and 0.008 , respectively) but not for either strawberry cultivar, raspberry, or lettuce $(P=0.324$ for raspberry and $P>0.999$ for both strawberry cultivars and lettuce) (Fig. 3).

Survival of $F$. oxysporum f. sp. fragariae in soil for 44 weeks after crop growth and plant tissue incorporation. Soil inoculum density. Experiment but not crop treatment had a significant effect on $\log _{2}$ (GL1080-K CFU/g of soil) at the time of plant tissue incorporation (experiment, $P=0.002$; crop, $P=0.155$; cropexperiment interaction, $P=0.896$; two-way ANOVA with crop as a fixed effect, experiment as a random effect, and interaction as a random effect). Total variance increased significantly between the time of incorporation and 12 wpi (Supplementary Fig. S2). Twoway ANOVA with the linear mixed model described above showed a significant crop effect for soil population densities at 12, 24, and 44 wpi $(P<0.001)$, and a significant experiment effect only at 12 wpi $(P<0.001)$. A repeated-measures ANOVA was conducted to assess the significance of time on soil population densities of GL1080-K. Crop, time, and crop-time interactions were considered fixed effects, and all were highly significant $(P<0.001)$.

Crop treatments were compared based on changes in soil inoculum densities of GL1080-K that occurred between plant incorporation and later time points. To accomplish this analysis, differences (i.e., $\Delta \log _{2}(\mathrm{GL} 1080-\mathrm{K} \mathrm{CFU/g})$ ) were calculated between population densities at 12,24 , and 44 wpi and the time of incorporation (0 wpi) for each pot (biological replicate) (Fig. 4). Two-way ANOVAs with $\Delta \log _{2}(\mathrm{GL} 1080-\mathrm{K} \mathrm{CFU/g})$ as the dependent variable, crop as a fixed effect, and experiment and crop-experiment interaction as random effects were conducted for each time point. These analyses revealed a significant experiment effect only at 12 wpi $(P<0.001)$, whereas all other random effects from all time points were not significant $(P>0.999)$. Tukey's HSD groups were calculated for 24 and 44 wpi (Supplementary Table S1). These analyses revealed that, for both time points, soil in pots where raspberry was grown had significantly higher inoculum densities than soil in pots in which other crops were grown. For lettuce, broccoli, and spinach, inoculum densities at 24 wpi were not significantly different from the fallow (no plant) treatment.

Recovery of plant tissue fragments at 44 wpi. Crop was a highly significant $(P<0.001$; two-way ANOVA) source of variation in weight of plant tissues recovered at 44 wpi $(P>0.999$ for random effects; experiment and crop-experiment interaction). Significantly more tissue was recovered from perennial crops (raspberry and strawberry) compared with annual crops (Table 4), and this rate of recovery was not correlated with fresh weight of plant tissues at the time of incorporation (data not shown).

Population densities of GL1080-K on recovered tissue fragments. Two-way ANOVAs conducted on the GL1080-K population density $\left(\log _{2}[\mathrm{CFU}+1 / \mathrm{g}]\right)$ in tissues recovered at 44 wpi also revealed a highly significant crop effect $(P<0.001)$ and no significant random effect terms $(P>0.999$ for both experiment and crop-experiment interaction) (Table 4).

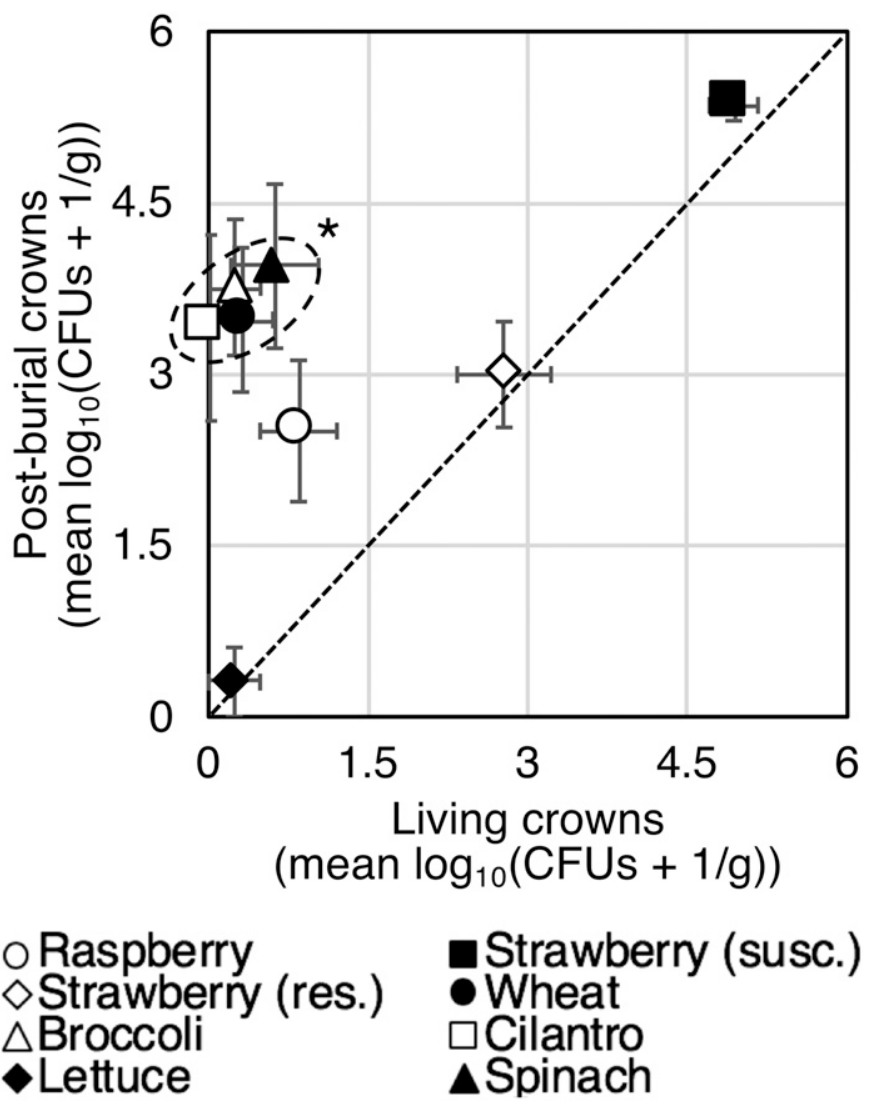

Fig. 3. Fusarium oxysporum f. sp. fragariae (GL1080-K) population density on living and two-week-postburial taproots or crowns. Plants were grown for 6 weeks in potting soil infested with GL1080-K at $2 \times 10^{5} \mathrm{CFU} / \mathrm{g}$ of soil. Living crowns were assayed immediately at 6 weeks post planting, and postburial crowns were assayed 2 weeks after being buried in soil in the pots in which they were grown. Mean $\log _{10}(\mathrm{CFU}+1 / \mathrm{g})$ of GL1080-K from total living crown tissues are shown on the $\mathrm{X}$-axis, and postburial GL1080-K population densities are on the $y$-axis. Error bars denote standard error of the mean. Significantly higher postburial GL1080-K population densities (versus GL1080-K populations on living crowns of the same crop) are denoted by an asterisk $\left(^{*}\right)(P<0.05)$. Strawberry cultivars were either resistant (San Andreas) or susceptible (Albion) to Fusarium wilt of strawberry.

TABLE 3. Colonization of lettuce taproot tissues by Fusarium oxysporum f. sp. fragariae ${ }^{\mathrm{w}}$

\begin{tabular}{|c|c|c|c|c|}
\hline Crop (cultivar) ${ }^{\mathrm{x}}$ & Leaf habit & Susceptibility ${ }^{\mathrm{y}}$ & Cortex $^{z}$ & Stele $^{z}$ \\
\hline Lettuce (Bondi) & Romaine & Susceptible & $0.21(0.21) \mathrm{a}$ & $0.49(0.25) \mathrm{a}$ \\
\hline Lettuce (Green Towers) & Romaine & Resistant & $0(0) \mathrm{a}$ & $0.14(0.14) \mathrm{a}$ \\
\hline Lettuce (Salinas 88) & Head & Susceptible & $0(0) \mathrm{a}$ & $0(0) \mathrm{a}$ \\
\hline Lettuce (Salute) & Head & Resistant & $0(0) \mathrm{a}$ & $0.49(0.33) \mathrm{a}$ \\
\hline Strawberry (Albion) & N/A & N/A & $4.41(0.43) b$ & $5.55(0.08) \mathrm{b}$ \\
\hline
\end{tabular}

${ }^{\mathrm{w}}$ Cortex of the taproot was assayed separately from the stele and stele of the taproot was assayed separately from the cortex. N/A = not applicable.

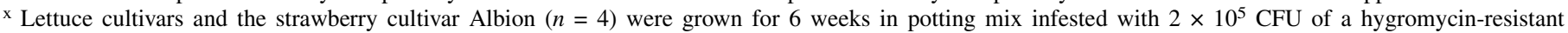
transformant of F. oxysporum f. sp. fragariae per gram of soil. Taproot or crown cortex and stele tissues were then assayed to determine the population density (CFU per gram of tissue) of the transformant.

y Lettuce cultivars were either resistant or susceptible to Fusarium wilt of lettuce, caused by F. oxysporum f. sp. lactucae.

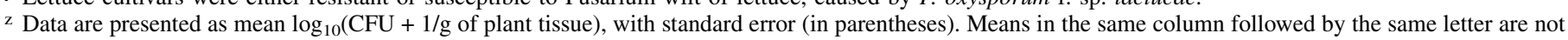
statistically different by Tukey's honestly significant difference test for multiple comparisons $(\alpha=0.05)$. The average limit of detection in these assays was 187 $\mathrm{CFU} / \mathrm{g}$. 
Soil and plant tissue population densities of GL1080-K (44 wpi) were compared within treatments by paired $t$ tests. Significantly higher population densities of GL1080-K were observed in tissues from raspberry and both strawberry cultivars compared with soil populations in their corresponding pots $(P<0.001)$. For spinach and cilantro, population densities of GL1080-K were significantly lower in tissue than in soil ( $P=0.005$ and $P=0.032$, respectively). The difference between tissue and soil was not significant for the wheat, lettuce, or broccoli treatments $(P>0.999, P=0.212$, and $P=0.500$, respectively).

A weak but significant positive correlation was observed between CFU of GL1080-K per gram of tissue fragments recovered at 44 wpi and mean soil CFU/g from 12, 24, and 44 wpi $(n=78)$. Biological replicates from which tissue fragments were not recovered were excluded from this analysis. $R^{2}$ values for 12,24 , and 44 wpi were $0.31,0.37$, and 0.36 respectively, all of which were highly significant $(P<0.001)$ (Supplementary Fig. S3). The $R^{2}$ value was 0.43 for tissue $\mathrm{CFU} / \mathrm{g}$ versus soil $\mathrm{CFU} / \mathrm{g}$ at 44 wpi when extreme outliers (i.e., points that were more than 4.5 times the interquartile range; $n=72$ ) were excluded (Fig. 5).

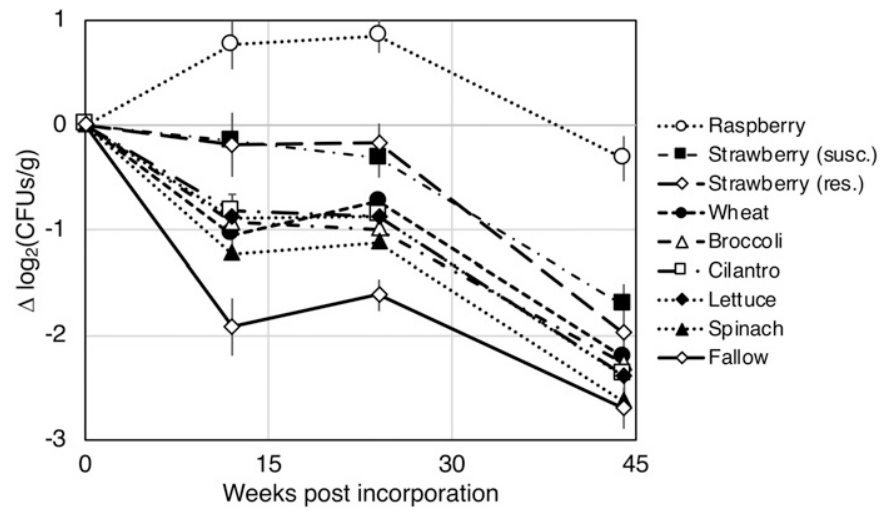

Fig. 4. Changes in mean soil population densities of Fusarium oxysporum f. sp. fragariae (GL1080-K) after crop debris incorporation. Plants $(n=4)$ were grown for 6 weeks in field soil infested with GL10800-K. Tissues were then fragmented and incorporated into soil from the pot where they were grown. Soil was assayed from each pot to determine the population density of GL1080-K at 0, 12, 24, and 44 weeks postincorporation. Differences between GL1080-K CFU/g of soil at 12, 24, and 44 weeks postincorporation and the time of crop debris incorporation (i.e., $\Delta \log _{2}[\mathrm{CFU} / \mathrm{g}]$ ) are plotted on the $\mathrm{y}$-axis. Error bars denote standard error of the mean. Strawberry cultivars were either resistant (San Andreas) or susceptible (Albion) to Fusarium wilt of strawberry.

\section{DISCUSSION}

This study shows, for the first time, a clear relationship between reproduction on asymptomatic hosts and long-term soil persistence for a Fusarium wilt pathogen. All crops and cultivars tested could be infected by $F$. oxysporum f. sp. fragariae but significant differences were observed in the extent of reproduction in their tissues. Annual crops (broccoli, lettuce, spinach, wheat, and cilantro) supported the lowest population densities of $F$. oxysporum f. sp. fragariae. Raspberry and Fusarium wilt-resistant strawberry cultivars supported populations and infection rates that were consistently closest to those observed on a susceptible strawberry cultivar. Population densities on asymptomatic hosts were typically greater after residue incorporation, highlighting the need to consider this phase of pathogen growth and reproduction in evaluating potential rotation crops.

Long-term experiments in infested fields directly assess the utility of crop rotations but such sites are not always available for research. In their absence, the methods used in our soil survival experiments provide a useful template for assessing inoculum production on asymptomatic hosts. Artificially infesting soil with an antibiotic selectable transformant enables rapid quantification of the pathogen in soil and in host tissue. Although these experiments can only be conducted in controlled environments, field soil can be used so that the pathogen must compete with naturally occurring microbes. A repetition of experiments using soils that differ in physicochemical properties and the composition of the microbiota would extend the generality of findings obtained with soil from a single field.

Assaying soil populations at multiple time points and tissue populations after a long incubation period (such as 44 weeks) can provide a useful indication of the plant's total inoculum contribution to soil. Soilborne populations observed by this procedure reflect total growth from rhizosphere, saprophytic activity in soil, and growth after decomposition of all tissue types. Plant species and tissues decompose at different rates (Birouste et al. 2012); thus, assaying tissues at the end of the incubation period is necessary to reveal inoculum that has not yet been released into the soil. For these reasons, the soil survival experiments described in this study are likely to be straightforward and effective for identifying crops that pose a risk for pathogen persistence.

Data on colonization of living plant tissues by $F$. oxysporum $\mathrm{f}$. $\mathrm{sp}$. fragariae suggest that raspberry would pose a greater threat than other nonstrawberry crops for maintaining soilborne populations of this pathogen. The magnitude of this threat is much greater when the

TABLE 4. Weight of, and Fusarium oxysporum f. sp. fragariae (GL1080-K) population densities (Density) on, plant tissues recovered 44 weeks post plant incorporation into soil ${ }^{\mathrm{x}}$

\begin{tabular}{lcc}
\hline Crop & Density $\log _{2}(\mathrm{CFU} / \mathrm{g})^{\mathrm{y}}$ & Weight of tissue $(\mathrm{g})^{\mathrm{y}}$ \\
\hline Raspberry & $13.9(0.3) \mathrm{a}$ & $1.1(0.19) \mathrm{b}$ \\
Strawberry (San Andreas): Allz & $11.2(0.4) \mathrm{ab}$ & $1.4(0.18) \mathrm{a}$ \\
$\quad$ Transport root & $11.1(0.6)$ & $0.6(0.13)$ \\
$\quad$ Crown & $11.0(0.5) \mathrm{c}(0.12)$ & $0.8(.7(0.22) \mathrm{ab}$ \\
Strawberry (Albion): All ${ }^{\mathrm{z}}$ & $10.7(0.3) \mathrm{ab}$ & $0.6(0.07)$ \\
$\quad$ Transport root & $10.7(0.4)$ & $1.0(0.18)$ \\
$\quad$ Crown & $10.5(0.3) \mathrm{c}$ & $0.2(0.03) \mathrm{c}$ \\
Wheat & $9.9(1.1) \mathrm{b}$ & $0.3(0.03) \mathrm{c}$ \\
Broccoli & $9.4(0.5) \mathrm{b}$ & $0.1(0.01) \mathrm{c}$ \\
Lettuce & $5.3(1.2) \mathrm{c}$ & $0.1(0.02) \mathrm{c}$ \\
Cilantro & $3.7(1.2) \mathrm{c}$ & $0.03(0.01) \mathrm{c}$ \\
Spinach & $3.3(1.1) \mathrm{c}$ & $\mathrm{c}$ \\
\hline
\end{tabular}

x Plants $(n=4)$ were grown for 6 weeks in field soil infested with a hygromycin-resistant transformant of $F$. oxysporum f. sp. fragariae; then, tissues were fragmented and incorporated into the soil. Tissue fragments that did not pass through a 4-mm mesh sieve 44 weeks post plant incorporation sieve were recovered, weighed, and assayed to determine the abundance of $F$. oxysporum f. sp. fragariae.

y Data are presented as mean and standard error (in parentheses). Means in the same column followed by the same letter are not significantly different by Tukey's honestly significant difference test for multiple comparisons $(\alpha=0.05)$.

${ }^{z}$ Strawberry transport roots and crown tissues were separated by morphology and assayed separately to determine the density of GL1080-K they contained. The weighted average between these two values is shown in the "All" strawberry tissue row for each of the cultivars. 
consequences of residue incorporation are taken into account. The density of $F$. oxysporum f. sp. fragariae $\mathrm{CFU} / \mathrm{g}$ in raspberry tissue fragments at 44 wpi was more than 10 times greater than what was observed in the most densely colonized living raspberry tissues. This indicates that pathogen exploitation of tissue following incorporation into soil can greatly amplify the amount of inoculum added to the soil population. This observation suggests that any evaluation of rotation crops should include assays of pathogen populations after crop residue incorporation.

The $F$. oxysporum $\mathrm{f}$. sp. fragariae-resistant cultivars tested in our experiments are heterozygous for a single, dominant resistance gene: $F w l$ (Pincot et al. 2018). In these cultivars, significantly lower inoculum densities were observed in the vascular stele than in cortical tissues. This suggests that $F w 1$-mediated resistance limits access to vascular tissues but does not prevent colonization of cortical tissues. These results are consistent with previous reports showing that pathogenic strains of $F$. oxysporum can extensively colonize resistant cultivars of their preferred hosts (Elmer and Lacy 1987; Gordon et al. 1989; Houterman et al. 2009; Rishbeth 1955; Scott et al. 2014; van der Does et al. in press). What are the genetic determinants that enable $F$. oxysporum f. sp. fragariae to colonize resistant cultivar cortical tissues at a significantly greater level than other crops? Do the same factors enable colonization of raspberry? Such questions have received little attention in the literature but have significant implications for our understanding of host specificity and the persistence of Fusarium wilt pathogens in the absence of their preferred host.

It is intriguing to note that raspberry, the most extensively colonized rotation crop in our study, is more closely related to strawberry than the other crops tested. Consistent with our findings, previous studies showed other Fusarium wilt pathogens to reproduce more extensively on plants that are in the same family as their preferred host (Dhingra and Coelho Netto 2001; Haware and Nene 1982). Furthermore, a wilt disease of raspberry caused by F. oxysporum was recently reported in Peru, and the causal agent was also pathogenic to strawberry (Martin et al. 2017). Likewise, a recently described pathogen of blackberry, F. oxysporum f. sp. mori, is also pathogenic to strawberry (Pastrana et al. 2017b). These observations suggest that there are common genetic determinants of susceptibility to $F$. oxysporum in raspberry, blackberry, and strawberry. Analysis of asymptomatic plant colonization in plant species other than the preferred host may provide insight into the prerequisites for host-specific pathogenicity in the F. oxysporum species complex.

Given that our results are consistent with past literature showing that formae speciales typically can extensively colonize plants that are closely related to their preferred host, our results may be applicable to other genotypes of $F$. oxysporum f. sp. fragariae. GL1080 is in the most common somatic compatibility group in California but two other somatic compatibility groups have been observed in California at a low frequency (Henry et al. 2017). Furthermore, isolates of $F$. oxysporum which can cause disease on strawberry have a global distribution, and limited information is available on their diversity (Koike and Gordon 2015). Future experiments could test the hypothesis that other genotypes of F. oxysporum f. sp. fragariae colonize rotation crops to an extent similar to that of GL1080.

Whereas soil survival experiments can assess total inoculum contribution to soil, data from infection of living plant tissues can provide information about where this inoculum is being produced. For example, our data suggest that localized fine root infections serve as an important site of $F$. oxysporum f. sp. fragariae population growth on some asymptomatic hosts but not on the susceptible strawberry cultivar Albion. Fine roots have a greater surface area/volume ratio than crowns and, therefore, are more likely to come into proximity of soilborne propagules of F. oxysporum f. sp. fragariae. If infections remain localized, many fine root infections, resulting from a 5 to $20 \%$ rate of root infection
(Fig. 1), would be expected to contribute more to soilborne inoculum than a limited number of localized crown infections. In contrast, the greatest population densities on the susceptible strawberry cultivar Albion occurred on crown stele tissues, which reflects more extensive colonization of these tissues compared with fine roots. Diverse root structure and function can exist within fine roots defined by diameter (McCormack et al. 2015), and future research may uncover additional patterns of colonization that are specific to root function.

Past research has shown that fields can remain infested for decades by Fusarium wilt pathogens in the absence of a susceptible host (Rishbeth 1955; Smith et al. 2001). However, the rate of soilborne pathogen population decline observed here and in other studies (Banihashemi and Dezeeuw 1973; Elmer and Lacy 1987; Gordon and Koike 2015; Rishbeth 1955; Scott et al. 2012; Stover 1956; Vakalounakis and Chialkas 2004) suggests that few chlamydospores survive long enough to account for pathogen persistence over many years. Rather, it seems likely that persistence of Fusarium wilt pathogens is attributable to their activity as parasites of nonsusceptible crops and their ability to further colonize host tissue as it decomposes.

Long-term survival in soil may be enhanced when pathogen propagules are embedded in recalcitrant plant tissues. The density of pathogen populations on strawberry and raspberry tissues averaged 4 to 12 times higher than that of the surrounding soil. Thus, tissues that are slow to degrade may extend the interval during which a pathogen is protected from attrition in the bulk soil environment, thereby increasing the risk for persistence associated with perennial crops.

The length of rotation required before a susceptible host can be grown depends on many factors, including the threshold of inoculum required to cause disease. Rishbeth (1955) observed that F. oxysporum f. sp. cubense was typically undetectable within 8 years after a banana crop, yet this interval did not prevent development of disease in susceptible banana crops. The assay procedure used by Rishbeth (1955) had an estimated detection threshold of 2 propagules/g. Such a low density of inoculum may be sufficient to cause disease in perennial crops such as banana because the probability of rare infection events will increase as roots

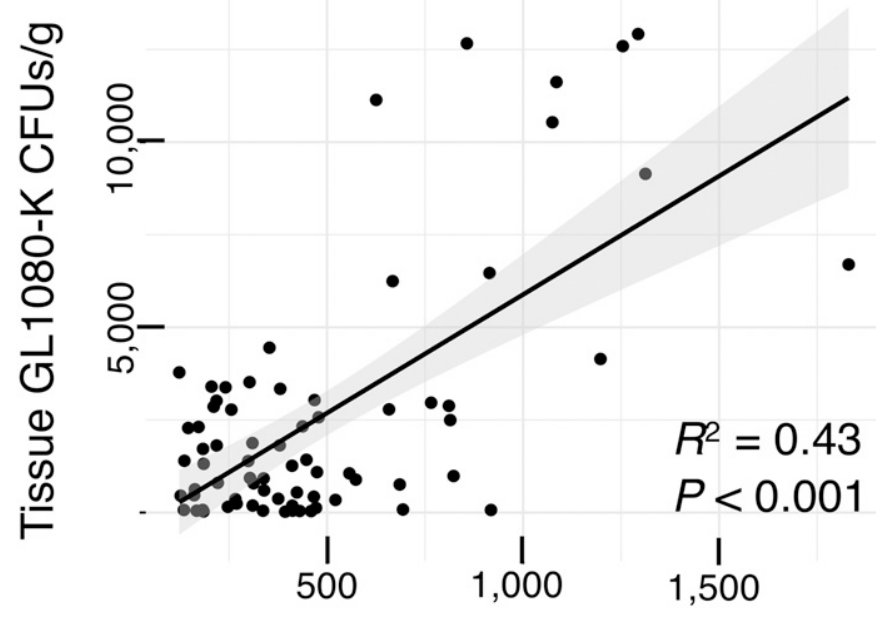

\section{Soil GL1080-K CFUs/g}

Fig. 5. Correlation between Fusarium oxysporum f. sp. fragariae (GL1080-K) $\mathrm{CFU}$ per gram of soil and tissues recovered at 44 weeks postinoculation. Plants $(n=4)$ were grown for 6 weeks in field soil infested with GL10800-K, then fragmented and incorporated into the soil. At 44 weeks postincorporation, GL1080-K population densities were determined from tissue fragments $>4 \mathrm{~mm}$ in size (y-axis) and soil (x-axis). Each point represents a single pot (biological replicate). Pots from which values were beyond 4.5 times the interquartile range for either soil or tissue CFU/g were excluded from this analysis $(n=72)$. 
explore the soil over time. In contrast, F. oxysporum f. sp. lactucae at $>100 \mathrm{CFU} / \mathrm{g}$ would be unlikely to cause economically damaging losses in lettuce, a 65- to 80-day crop, even on a susceptible cultivar (Paugh and Gordon in press).

The inoculum threshold for observing disease by $F$. oxysporum f. sp. fragariae on strawberry has not been characterized but 50 to 70 $\mathrm{CFU} / \mathrm{g}$ have been observed in heavily diseased fields (P. M. Henry, unpublished data). The threshold for disease may be quite low for strawberry, given that plantings are maintained for 6 to 12 months. Consequently, crop rotation should be supplemented by other disease management strategies such as cultivar selection.

Core findings from this study are congruent with past observations and likely to be broadly relevant in Fusarium wilt pathosystems. Most crops are expected to support asymptomatic infection by Fusarium wilt pathogens but crops may differ in the extent to which they become colonized. F. oxysporum is likely to grow more extensively after incorporation of crop residue, indicating that assays of only living plant tissues may not provide a complete picture of the impact on pathogen soil populations. Infection of fine roots appears to be the rule for Fusarium wilt pathogens and, presumably, is a mechanism by which persistence can occur for extended periods in the absence of a susceptible host. However, if infections remain localized, fine root colonization would not be expected to prevent a significant decline in soil inoculum density over time (Gordon 2017). On the other hand, the more extensive colonization that can occur in transport roots and crown or taproot tissues could significantly reduce the anticipated benefit of crop rotation. Resistant cultivars and crops that are closely related to the susceptible host may pose a greater risk for pathogen population growth and persistence in soil. Future controlledenvironment experiments designed to assess the extent to which asymptomatic hosts support growth of Fusarium wilt pathogens should include assays of host tissues and soil after incorporation of crop residue.

\section{ACKNOWLEDGMENTS}

We thank M. Najarro, L. Lopez, M. Munji, S. Koehler, M. Haugland, M. Alba, and B. Jenner for technical assistance with experiments.

\section{LITERATURE CITED}

Banihashemi, Z., and Dezeeuw, D. J. 1973. The effect of soil temperature on survival of Fusarium oxysporum f. sp. melonis (Leach and Currence) Snyder and Hansen. Plant Soil 38:465-468.

Birouste, M., Kazakou, E., Blanchard, A., and Roumet, C. 2012. Plant traits and decomposition: Are the relationships for roots comparable to those for leaves? Ann. Bot. 109:463-472.

Bundock, P., den Dulk-Ras, A., Beijersbergen, A., and Hooykaas, P. J. J. 1995. Trans-kingdom T-DNA transfer from Agrobacterium tumefaciens to Saccharomyces cerevisiae. EMBO J. 14:3206-3214.

Correll, J. C., Klittich, C. J. R., and Leslie, J. F. 1987. Nitrate nonutilizing mutants of Fusarium oxysporum and their use in vegetative compatibility tests. Phytopathology 77:1640-1646.

de Mendiburu, F. 2017. agricolae: Statistical procedures for agricultural research. https://cran.r-project.org/web/packages/agricolae/index.html

Dhingra, O. D., and Coelho Netto, R. A. 2001. Reservoir and non-reservoir hosts of bean wilt pathogen, Fusarium oxysporum f. sp. phaseoli. J. Phytopathol. 149:463-467.

Elmer, W. H., and Lacy, M. L. 1987. Effects of crop residues and colonization of plant tissues on propagule survival and soil populations of Fusarium oxysporum f. sp. apii race 2. Phytopathology 77:381-387.

Fang, X., Phillips, D., Li, H., Sivasithamparam, K., and Barbetti, M. J. 2011. Severity of crown and root diseases of strawberry and associated fungal and oomycete pathogens in Western Australia. Australas. Plant Pathol. 40: 109-119.

Fox, J., and Weisberg, S. 2011. An $\{$ R $\}$ Companion to Applied Regression. Sage, Thousand Oaks, CA, U.S.A.

Gatch, E. W., and du Toit, L. J. 2017. Limestone-mediated suppression of Fusarium wilt in spinach seed crops. Plant Dis. 101:81-94.

Gordon, T. R. 2017. Fusarium oxysporum and the Fusarium wilt syndrome. Annu. Rev. Phytopathol. 55:23-39.
Gordon, T. R., and Koike, S. T. 2015. Management of Fusarium wilt of lettuce. Crop Prot. 73:45-49.

Gordon, T. R., and Okamoto, D. 1990. Colonization of crop residue by Fusarium oxysporum f. sp. melonis and other species of Fusarium. Phytopathology 80:381-386.

Gordon, T. R., and Okamoto, D. 1991. Vegetative compatibility groupings in a local population of Fusarium oxysporum. Can. J. Bot. 69:168-172.

Gordon, T. R., Okamoto, D., and Jacobson, D. J. 1989. Colonization of muskmelon and nonsusceptible crops by Fusarium oxysporum f. sp. melonis and other species of Fusarium. Phytopathology 79:1095-1100.

Gordon, T. R., Stueven, M., Pastrana, A. M., Dennehy, C., Kirkpatrick, S. C., Henry, P. M., and Daugovish, O. The effect of $\mathrm{pH}$ on spore germination, growth and infection of strawberry roots by Fusarium oxysporum f. sp. fragariae, cause of Fusarium wilt of strawberry. Plant Dis. In press. doi.org/ 10.1094/PDIS-08-18-1296-RE

Haware, M. P., and Nene, Y. L. 1982. Symptomless carriers of the chickpea wilt Fusarium. Plant Dis. 66:250-251.

Henry, P. M., Kirkpatrick, S. C., Islas, C. M., Pastrana, A. M., Yoshisato, J. A., Koike, S. T., Daugovish, O., and Gordon, T. R. 2017. The population of Fusarium oxysporum f. sp. fragariae, cause of Fusarium wilt of strawberry, in California. Plant Dis. 101:550-556.

Hopkins, D. L., and Elmstrom, G. W. 1984. Effect of nonhost crop plants on watermelon Fusarium wilt. Plant Dis. 68:239-241.

Houterman, P. M., Ma, L., van Oooijen, G., de Vroomen, M. J., Cornelissen, B. J. C., Takken, F. L. W., and Rep, M. 2009. The effector protein Avr2 of the xylem-colonizing fungus Fusarium oxysporum activates the tomato resistance protein I-2 intracellularly. Plant J. 58:970-978.

Kemppainen, M., Circosta, A., Tagu, D., Martin, F., and Pardo, A. G. 2005. Agrobacterium-mediated transformation of the ectomycorrhizal symbiont Laccaria bicolor S238N. Mycorrhiza 16:19-22.

Kettler, T. A., Doran, J. W., and Gilbert, T. L. 2001. Simplified method for soil particle-size determination to accompany soil-quality analyses. Soil Sci. Soc. Am. J. 65:849-852.

Koike, S. T., and Gordon, T. R. 2015. Management of Fusarium wilt of strawberry. Crop Prot. 73:67-72.

Komada, H. 1975. Development of a selective medium for quantitative isolation of Fusarium oxysporum from natural soils. Rev. Plant Prot. Res. 8: 114-125.

Kuznetsova, A., Brockhoff, P. B., and Christensen, R. H. B. 2017. lmerTest package: Tests in linear mixed effects models. J. Stat. Softw. 82:1-26.

Leoni, C., de Vries, M., Braak, C. J. F., van Bruggen, A. H. C., and Rossing, W. A. H. 2013. Fusarium oxysporum f. sp. cepae dynamics: In-plant multiplication and crop sequence simulations. Eur. J. Plant Pathol. 137: 545-561.

Lloyd, M. G. 2015. Strawberry production and management of soilborne diseases in the post-fumigation era. Ph.D. dissertation, University of California ProQuest, Davis, U.S.A.

Martin, R. R., Ellis, M. A., Williamson, B., and Williams, R. N., eds. 2017. Compendium of Raspberry and Blackberry Diseases and Pests. The American Phytopathological Society, St. Paul, MN, U.S.A.

McCormack, M. L., Dickie, I. A., Eissenstat, D. M., Fahey, T. J., Fernandez, C. W., Guo, D., Helmisaari, H., Hobbie, E. A., Iversen, C. M., Jackson, R. B., Leppalammi-Kujansuu, J., Norby, R. J., Phillips, R. P., Pregitzer, K. S., Pritchard, S. G., Rewald, B., and Zadworny, M. 2015. Redefining fine roots improves understanding of below-ground contributions to terrestrial biosphere processes. New Phytol. 207:505-518.

Mullins, E. D., Chen, X., Romaine, P., Raina, R., Geiser, D. M., and Kang, S. 2001. Agrobacterium-mediated transformation of Fusarium oxysporum: An efficient tool for insertional mutagenesis and gene transfer. Phytopathology 91:173-180.

Nageswara Rao, V., Sastry, R. K., Craufurd, P., Meinke, H., Parsons, D., Rego, T. J., and Rathore, A. 2014. Cropping systems strategy for effective management of Fusarium wilt in safflower. Field Crops Res. 156:191-198.

Pareek, M., Sachdev, M., Tetorya, M., and Rajam, M. V. 2015. Glass-bead and Agrobacterium-mediated genetic transformation of Fusarium oxysporum. Pages 169-174 in: Genetic Transformation Systems in Fungi, Vol. 1. M. A. van den Berg and K. Maruthachalam, eds. Springer International Publishing, Switzerland.

Pastrana, A. M., Basallote-Ureba, M. J., and Capote, N. 2017a. Symptomless reservoirs of Fusarium oxysporum f. sp. fragariae and alternative hosts of Fusarium solani pathogenic to strawberry. J. Plant Pathol. 99:141-148.

Pastrana, A. M., Kirkpatrick, S. C., Kong, M., Broome, J. C., and Gordon, T. R. 2017b. Fusarium oxysporum f. sp. mori, a new forma specialis causing Fusarium wilt of blackberry. Plant Dis. 101:2066-2072.

Paugh, K. R., and Gordon, T. R. The effect of planting date and inoculum density on severity of Fusarium wilt of lettuce in California. Plant Dis. https://doi.org/10.1094/PDIS-09-18-1614-RE

Pincot, D. D. A., Poorten, T. J., Hardigan, M. A., Harshman, J. M., Acharya, C. B., Cole, G. S., Gordon, T. R., Stueven, M., Edger, P. P., and Knapp, S. 
2018. Genome-wide association mapping uncovers $F w 1$, a dominant gene conferring resistance to Fusarium wilt in strawberry. G3: Genes Genomes Genet. 8:1817-1828.

R Core Team. 2013. R: A Language and Environment for Statistical Computing. R Foundation for Statistical Computing, Vienna, Austria.

Rishbeth, T. 1955. Fusarium wilt of bananas in Jamaica: Some observations on the epidemiology of the disease. Ann. Bot. 19:293-328.

Scott, J. C., Gordon, T. R., Kirkpatrick, S. C., Koike, S. T., Matheron, M. E., Ochoa, O. E., Truco, M. J., and Michelmore, R. W. 2012. Crop rotation and genetic resistance reduce risk of damage from Fusarium wilt in lettuce. Calif. Agric. J. 66:20-24.

Scott, J. C., McRoberts, N., and Gordon, T. R. 2014. Colonization of lettuce cultivars and rotation crops by Fusarium oxysporum f. sp. lactucae, the cause of Fusarium wilt of lettuce. Plant Pathol. 63:548-553.

Smith, S. N., DeVay, J. E., Hsieh, W., and Lee, H. 2001. Soil-borne populations of Fusarium oxysporum $\mathrm{f}$. sp. vasinfectum, a cotton wilt fungus in California fields. Mycologia 93:737-743.

Stover, R. H. 1956. Studies on Fusarium wilt of bananas: I. The behavior of F. oxysporum f. sp. cubense in different soils. Can. J. Bot. 34: 927-942.
Suga, H., Hirayama, Y., Morishima, M., Suzuki, T., Kageyama, K., and Hyakumachi, M. 2013. Development of PCR primers to identify Fusarium oxysporum f. sp. fragariae. Plant Dis. 97:619-625.

Toledo-Souza, E. D., Silveira, P. M., Cafe-Filho, A. C., and Junior, M. J. 2012. Fusarium wilt incidence and common bean yield according to the preceding crop and the soil tillage system. Pesqui. Agropecu. Bras. 47:1031-1037.

Vakalounakis, D. J., and Chialkas, J. 2004. Survival of Fusarium oxysporum f. sp. radicis-cucumerinum in soil. Crop Prot. 23:871-873.

van der Does, H. C., Constantin, M. E., Houterman, P. M., Takken, F. L. W., Cornelissen, B. J. C., Haring, M. A., van den Burg, H. A., and Rep, M. Fusarium oxysporum colonizes the stem of resistant tomato plants, the extent varying with the R-gene present. Eur. J. Plant Pathol. In press. doi. org/10.1007/s10658-018-1596-3

Wang, B., Li, R., Ruan, Y. O. Y., Zhao, Y., and Shen, Q. 2015. Pineapplebanana rotation reduced the amount of Fusarium oxysporum more than maize-banana rotation mainly through modulating fungal communities. Soil Biol. Biochem. 86:77-86.

Yuan, H., Ling, X., Liu, T., Chen, T., Yang, Y., Yao, S., and Zhang, B. 2014. Microscopic observations of strawberry plant colonization by a GFP-labeled strain of Fusarium oxysporum f. sp. fragariae. Can. J. Plant Pathol. 36:501-508. 